\title{
Iringan Kuda Lumping Ngesti Budaya
}

\author{
SUBUH $^{1}$ DAN YUNI PRASETYO \\ Jurusan Karawitan, Fakultas Seni Pertunjukan, Institut Seni Indonesia Yogyakarta
}

\begin{abstract}
Musical accompaniment of Ngesti Budaya horse dance. This article describes and analyzes a unique form performance, presentation structure and growth of accompaniment of Ngesti Budaya horse dance through a descriptive analysis method. This dance represents a performing art owning characteristic, colour and also typical motion. One of the typical characteristic or element of this genre is a role of its musical accompaniment. Musical accompaniment always accommodates dance movement pattern, assuring dance character, nguripke joget and develop; building dance plot atmosphere. At its growth, musical accompaniment does not only accompany dance, but with various its till can become important shares of dance and have to position is same in its presentation.
\end{abstract}

Key Words: Horse dance, trance, karawitan

\section{Pendahuluan}

Kuda lumping Ngesti Budaya Jragan Kecamatan Tembarak Kabupaten Temanggung, merupakan perkembangan dari kuda lumping karya almarhum R. Subagyono yang diciptakan sekitar tahun 1970 (hasil wawancara dengan Didik Nuryanto). Almarhum R. Subagyono adalah pakar dan pembina kuda lumping di Kabupaten Temanggung, karyanya telah diakui oleh masyarakat Temanggung sebagai kesenian tradisional sekaligus merupakan kesenian kebanggaan masyarakat Temanggung.

Salah satu ciri khas kuda lumping desa Jragan adalah peran iringannya. Tari kuda lumping karya R. Subagyono pada awalnya hanya menggunakan iringan dua gending. Kedua gending itu belum diberi nama dan belum diketahui siapa pembuat atau penciptanya.

Sejalan dengan pengaruh perkembangan zaman, kuda lumping Ngesti Budaya mengalami perkembangan pula dalam penataan tari maupun iringannya. Perubahan iringan tersebut mengikuti gerak tarinya, berupa pengembangan variasi lagu dan bentuk gending seperti lancaran dan sampak, namun tidak lepas dari bentuk iringan yang digunakan dalam tari kuda lumping karya almarhum R. Subagyono, yang berpijak pada pola gerak tari yaitu gebesan, cokehan, srimpetan, tolehan jangga (pacak jangga), ngombe, merakan, drap, congklang, tumpang tali, mager timun, lampah balik, lampah tiga, teposan, iyidan, sirig, bokongan dan lain-lain.

Tulisan ini akan membahas tentang ciri khas bentuk pertunjukan, struktur penyajian dan perkembangan garap iringan tari kuda lumping Ngesti Budaya yang berada di Desa Jragan Kecamatan Tembarak dengan menggunakan metode deskriptif analisis.

Soedarsono menyatakan bahwa iringan merupakan salah satu aspek yang memegang peranan penting. Iringan tidak hanya sebagai pelengkap tari, akan tetapi menjadi bagian dari tari itu sendiri. (Soedarsono, 1992:88). Pernyataan Soedarsono dipertegas oleh Rahayu Supanggah yang menyatakan bahwa musik atau iringan dalam tari bukan hanya sebagai iringan saja, tetapi juga menjadi kelengkapan tari yang sangat terkait untuk dapat memberikan suasana yang diinginkan sehingga mendukung alur cerita. Fungsi musik atau iringan tari adalah sebagai pemberi tanda perubahan gerak, memberi tanda

1 Alamat korespondensi: Jln. Parangtritis KM. 6,5 Sewon, Yogyakarta. Tlp. 0274-375380, e-mail: subuh.isi@gmail.com 
permulaan dan akhir penyajian. (Supanggah, 2002:14). Selanjutnya Supanggah mengatakan bahwa gending beksan atau tari berfungsi untuk mendukung keberhasilan penampilan tari, yang utama adalah bagaimana gending dapat menghidupkan tari, nguripke joged bukan sematamata mengiringi tari. Nguripke joged berarti memberi ruh dan karakter pada joged baik melalui tokoh tertentu maupun alur tari, alur cerita. Karawitan menyesuaikan dengan serangkaian pilihan gending atau lagu yang memiliki karakter dan/atau rasa yang sesuai dengan alur tari atau cerita, dibantu dengan garap gending yang meliputi berbagai aspek.

\section{Kesenian Kuda Lumping Ngesti Budaya}

Desa Jragan merupakan salah satu wilayah dari Kecamatan Tembarak Kabupaten Temanggung yang paling menonjol kehidupan keseniannya, khususnya kesenian Kuda lumping. Desa Jragan memiliki dua paguyuban kuda lumping yaitu Paguyuban Turonggo Seto dan Ngesti Budaya. Paguyuban kuda lumping Turonggo Seto berada di Dusun Dukuh Desa Jragan dan paguyuban kuda lumping Ngesti Budaya berada di Dusun Jragan Desa Jragan. Setiap paguyuban terdiri atas tiga kelompok yaitu kelompok 1 dewasa umur 17 sampai 35 tahun, kelompok 2 siswa SLTP dan kelompok 3 siswa SD.

Kuda lumping Desa Jragan dibentuk pada tahun 1974 sebagai hasil sosialisasi kuda lumping dari Dinas Pembinaan Kebudayaan Kabupaten Temanggung di Desa Jragan. Dalam sosialisasi itu, Dinas Pembinaan Kebudayaan menampilkan tari massal kuda lumping binaannya dan dalam isi sambutan dari Bapak Soewartono selaku wakil dari Dinas Pembinaan Kebudayaan mengatakan bahwa, Dinas Pembinaan Kebudayaan akan memberikan pembinaan bagi masyarakat yang berminat untuk membentuk organisasi kuda lumping. (Wawancara dengan Turyono, tanggal 8 April 2010). Masyarakat Desa Jragan merespon adanya sosialisasi dengan mengadakan rapat yang menghasilkan kesepakatan untuk membentuk paguyuban kuda lumping. Sebagai tindak lanjut dari musyawarah, kemudian membentuk struktur organisasi yang diketuai oleh Turyono dan paguyuban tersebut dinamakan Ngesti Budaya. Ngesti berarti melestarikan dan budaya berarti hasil tingkah laku atau karya, jadi nama Ngesti Budaya berarti melestarikan hasil karya.

Kuda lumping Ngesti Budaya dilatih oleh R. Soebagyono yang kemudian dilanjutkan oleh Soewartono dan Sunaryo dari Dinas Pembinaan Kebudayaan yang waktu itu tergabung dalam IDAKEB (Ikatan Dinas Kebudayaan). IDAKEB merupakan lembaga yang bertugas sebagai Pembina kuda lumping dan seni lainnya di Kabupaten Temanggung. Tari dan iringan kuda lumping yang diajarkan yaitu karya Almarhum R. Soebagyono.

Dalam prosesperkembangannya, kudalumping Ngesti Budaya tidak lagi mendapat pembinaan dari IDAKEB, namun mereka mengembangkan kuda lumping menurut kemampuan dan selera mereka. Paguyuban kuda lumping Ngesti Budaya berusaha mengemas kuda lumping dalam bentuk baru dengan mengolah atau menggarap beberapa aspek yang terkait yaitu gerak, iringan, kostum, cerita dan lain-lain. Aspek yang paling menonjol perkembangannya yaitu aspek iringannya. Menurut Didik Nuryanto, hal itu terjadi karena rasa jenuh dengan iringan yang digunakan kuda lumping karya R. Soebagyono yang terkesan monoton. (Wawancara dengan Didik Nuryanto, tanggal 27 Maret 2010). Pengemasan dalam bentuk yang baru bertujuan agar kuda lumping Ngesti Budaya lebih diterima oleh masyarakat, karena banyaknya paguyuban kuda lumping di daerah Temanggung (Wawancara dengan Suroyo, tanggal 10 April 2010).

\section{Bentuk Penyajian}

Penyajian kuda lumping dibagi menjadi tiga bagian, yaitu bagian pambuka (pembukaan) yaitu penyajian karawitan sebelum tari kuda lumping dimulai, bagian tari kuda lumping dan bagian penutup. Pada bagian pembuka para panjak (pengrawit) melakukan penyajian gendinggending klasik maupun garapan, atau masyarakat kuda lumping lazim menyebut ampak-ampak. Bagian pembuka berfungsi sebagai tanda bahwa pertunjukan akan segera dimulai dan mengundang penonton. Pada bagian tengah penyajian gending pambuka disampaikan salam pambuka atau salam pambagya kepada penonton. Selanjutnya masuk pada bagian tari massal kuda lumping. Penyajian tari kuda lumping terdapat tiga tarian yaitu tari 
massal kuda lumping, tari gendruwo, dan tari singolodro. Setelah bagian tari kuda lumping selesai kemudian memasuki bagian akhir dari penyajian yakni bagian penutup. Pada bagian penutup disajikan gending penutup dan ucapan terima kasih serta permohonan maaf atas segala kesalahan paguyuban kuda lumping Ngesti Budaya kepada penonton dan paguyuban kuda lumping lainnya yang pada saat itu pentas bersama.

Di dalam penyajiannya, tari kuda lumping memiliki berbagai aspek antara lain pelaku dan tokoh dalam kuda lumping, cerita, gerak, tata rias dan busana, instrumen, waktu dan tempat pertunjukan. Instrumen yang digunakan dalam kesenian kuda lumping terdiri dari sebagian perangkat gamelan yang berlaras slendro dan pelog. Instrumen gamelan Jawa yang digunakan terdiri atas demung, saron, bende, angklung, kendang, kempul, gong suwukan, dan instrumen tambahan keyboard, snar drum dan bass drum.

\section{Perkembangan Iringan Tari Kuda Lump- ing Ngesti Budaya}

\section{Iringan Kuda Lumping Versi R. Soebagy- ono}

Pada awalnya, tari kuda lumping yang hidup dan berkembang di daerah Temanggung adalah tari kuda lumping karya almarhum R. Subagyono. Tari kuda lumping tersebut hanya menggunakan iringan dua gending. Kedua gending itu belum diberi nama dan belum diketahui siapa pembuat atau penciptanya. Salah satu contoh repertoar iringan kuda lumping adalah sebagai berikut.

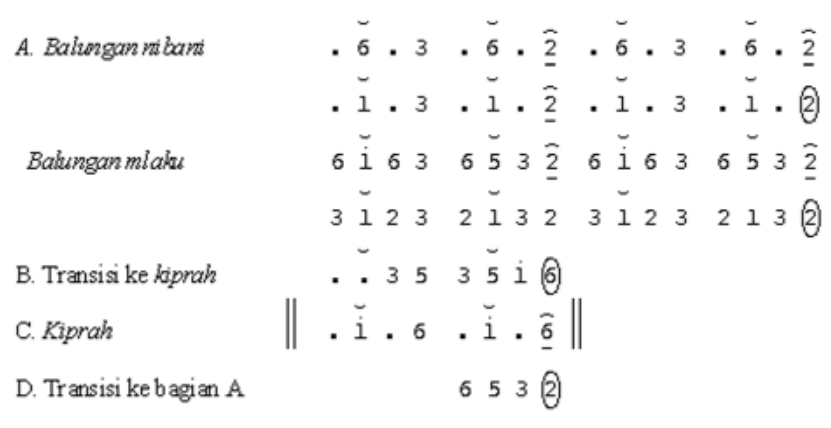

berdasarkan conton repertoar dı atas, maka dapat dideskripsikan struktur penyajian serta pola kendangannya, sebagai berikut.

\section{Struktur Penyajian}

Struktur penyajian gending dimulai dari buka oleh instrumen kendang dengan pola kendangan buka. Kendangan buka sama dengan pola kendangan transisi, kemudian katampen ricikan balungan dengan nada balungan bagian D kemudian masuk pada bagian A. Bagian A disajikan berulang-ulang, untuk menuju bagian $\mathrm{B}$ pengendang memainkan pola kendangan transisi. Bagian B disajikan satu kali, merupakan pola lagu transisi menuju bagian C. Bagian C disajikan berulang-ulang, kemudian kembali ke bagian A. Menuju bagian A pengendang memainkan pola kendangan transisi katampen nada balungan bagian D. Gending ini disajikan berulang-ulang sampai pertunjukan tari selesai.

\section{Garap Kendang}

Pola kendangan yang digunakan terdiri dari pola kendangan pinatut dan pola kendangan transisi.

a. Salah satu contoh Pola kendangan pinatut

$$
\begin{aligned}
& \text {. } t \overline{p l}+\overline{b b}+\overline{p l} \overline{d b} \overline{. b} \overline{t p} \overline{p p} \overline{t b} b \overline{t b} \overline{p l} d \\
& b \overline{t p} \overline{p p} \overline{t b} b \overline{t b} \overline{P l} \overline{d b} \overline{. b} \overline{t p} \overline{p p} \overline{t b} b \overline{t b} \overline{P l} d
\end{aligned}
$$

\section{b. Pola kendangan transisi}

$$
\overline{b d} b d t \quad b \quad d \quad P O
$$

Variasi pola kendangan versi R. Soebagyono merupakan dasar untuk membedakan pola gerak tari yang satu dengan yang lain. Pola kendangan transisi berfungsi sebagai tanda perpindahan pola gerak, contohnya dari lampah tiga ke iyidan atau sebaliknya. Kendang berfungsi pula sebagai pamurba irama untuk mempercepat dan memperlambat tempo sekaligus mengatur volume tabuhan.

\section{Perkembangan Garap Iringan Kuda Lum ping}

Bentuk kesenian kuda lumping Ngesti Budaya telah mengalami perubahan dari bentuk semula. Perubahan terjadi pada polairingan yangdigunakan yaitu penggunaan bentuk gending seperti lancaran dan sampak, serta bentuk khusus iringan kuda lumping dengan variasi lagu yang berbeda. Selain 
itu perubahan juga nampak pada pola iringan untuk beberapa pola gerak tari tertentu yang mempunyai pola khusus, namun masih merujuk pada bentuk iringan yang digunakan dalam tari kuda lumping karya almarhum R. Subagyono. Pola iringan tersebut yaitu gebesan, ngombe, drap, sirig jaran, jempolan, kosodan, congklang, lenjitan, iyidan, sirig, kirig bokongan, sembirang, kiprah yang terdiri dari kiprah sampur, kiprah gantung dan kiprah mubeng.

\section{Garap Balungan}

Ricikan balungan yang terdiri dari demung dan saron merupakan kelompok instrumen pembawa melodi atau lagu. Ricikan balungan dimainkan dengan tabuhan balungan nibani, mlaku dan tikel balungan tikel yaitu balungan yang memiliki harga setengah sabetan (dari balungan mlaku normal) pada semua balungan salah satu atau lebih bagian dari gending. (Supanggah, 2009: 59). Instrumen saron dimainkan dengan pola tabuhan imbal dan kinthilan.

\section{Garap Kempul dan Gong}

Instrumen kempul dan gong berfungsi sebagai pamangku irama, pemantap lagu yang berulangulang dan sebagai akhir pada suatu penyajian gending. Penyajian iringan kuda lumping Ngesti Budaya menggunakan beberapa macam bentuk gending yaitu lancaran, sampak dan bentukgending khusus iringan kuda lumping, yang berbeda dari bentuk gending dalam tradisi karawitan Jawa pada umumnya. Dalam iringan kuda lumping tersebut, terdapat struktur tabuhan kempul dan gong, namun tidak terdapat struktur tabuhan kenong. Meskipun demikian, dapat dilihat bahwa tabuhan kempul dan gong dapat menjadi indikator bentuk gending. Beberapa bentuk gending dapat dilihat berdasarkan struktur tabuhan berikut ini.

Bentuk gangsaran

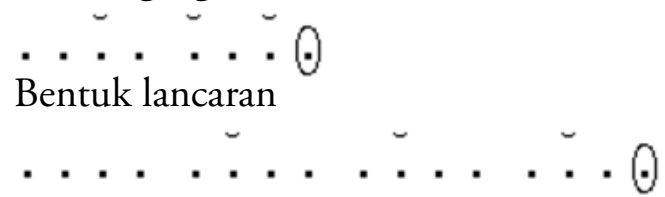

Bentuk sampak

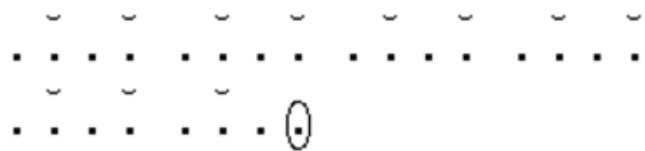

Bentuk di luar tradisi karawitan

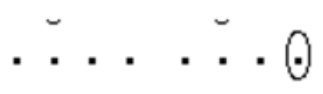

\section{Struktur Penyajian}

Penyajianiringankudalumpingterbagimenjadi tiga bagian yaitu bagian gending pambuka, bagian iringan tari kuda lumping dan gending penutup. Iringan tari kuda lumping diawali dengan gending bentuk lancaran sebagai berikut:

$$
\begin{aligned}
& \text { A }\left\|\cdot 5 \cdot 1 \cdot 5 \cdot 1 \cdot 5 \cdot 3 \cdot 2 \cdot \frac{1}{1}\right\| \\
& \text { B. } \cdot 5 \cdot 1 \cdot 5 \cdot 1 \cdot 5 \cdot 3 \cdot 2 \cdot 5
\end{aligned}
$$

Gending ini digunakan untuk mengiringi masuknya penari ke arena pentas. Bersamaan dengan masuknya penari, salah satu wiraswara membacakan lampahan cerita atau kandha. Setelah selesai kandha, pengendang melakukan kendangan transisi pada bagian B gatra ke-3 dan 4 kemudian masuk ke pola gerak sirig maju, dengan

\begin{tabular}{|c|c|c|c|c|}
\hline Pola lagu & $\cdot 6 \cdot 5$ & $.3 \cdot 5$ & $.5 \cdot 7$ & $\cdot \overline{6} \cdot \overline{5}$ \\
\hline Pola kendangan & $\cdots \cdot$ & $\cdots$ & $\overline{. d} . \bar{t}$ & $d t P$ \\
\hline Pola lagu & $\cdot 6 \cdot 5$ & $\cdot 3 \cdot 5$ & $\cdot 3 \cdot 2$ & .3. \\
\hline Pola kendangan & . . . & . . & .d. .t. & $d t P$ \\
\hline Pola lagu & $\cdot 2 \cdot 3$ & $\cdot 5 \cdot 3$ & $\cdot 2 \cdot 5$ & $\cdot 2 \cdot$ \\
\hline Pola kendangan & . . & $\cdot t \cdot d$ & $\overline{. d} \cdot d t$ & . d \\
\hline
\end{tabular}
pola iringan sebagai berikut.

Pola iringan ini menggunakan bentuk gending lancaran, merupakan susunan balungan nibani. Ricikan balungan yang terdiri atas demung dan saron, digarap dengan volume keras dan samasama memainkan balungan nibani. Pola kendangan disesuaikan dengan pola geraknya, sedangkan perubahan gerak ditandai dengan pola kendangan transisi pada gatra ke-11 dan 12, kemudian masuk pada pola gerak congklang. Berikut pola iringan gerak congklang.

Pola lagu

Pola snartbass

Pola lagu

Pola snartbass

Pola lagu

Pola snar + bass
.55 .555 .5553555

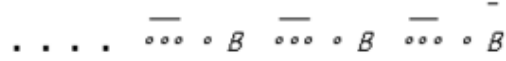

$.3 .2 .1 .2 . .11 . .11$

$\overline{000}, B \overline{000} \cdot \bar{B}_{000} \circ \overline{0.0} . B$

. . 11612121.2 .3 .6 .5

$\overline{00} \cdot B \overline{0} \cdot B \quad \overline{b d} b d t b d P O$ 
Pola iringan ini menggunakan bentuk gending lancaran. Susunan balungan terdiri dari balungan mlaku dan nibani. Balungan nibani terdapat pada gatra 5, 6, 11 dan 12. Variasi susunan balungan bertujuan untuk memperoleh kesan gecul atau gagah dengan mempertegas determinasi balungan. Dalam pola iringan ini, peran kendang diganti oleh snar drum dan bass drum yang berfungsi mempertegas gerak congklang. Perubahan gerak ditandai pola kendangan transisi pada gatra 11 dan 12 kemudian masuk ke pola gerak kombinasi yang terdiri dari beberapa pola gerak. Berikut pola iringan gerak kombinasi.

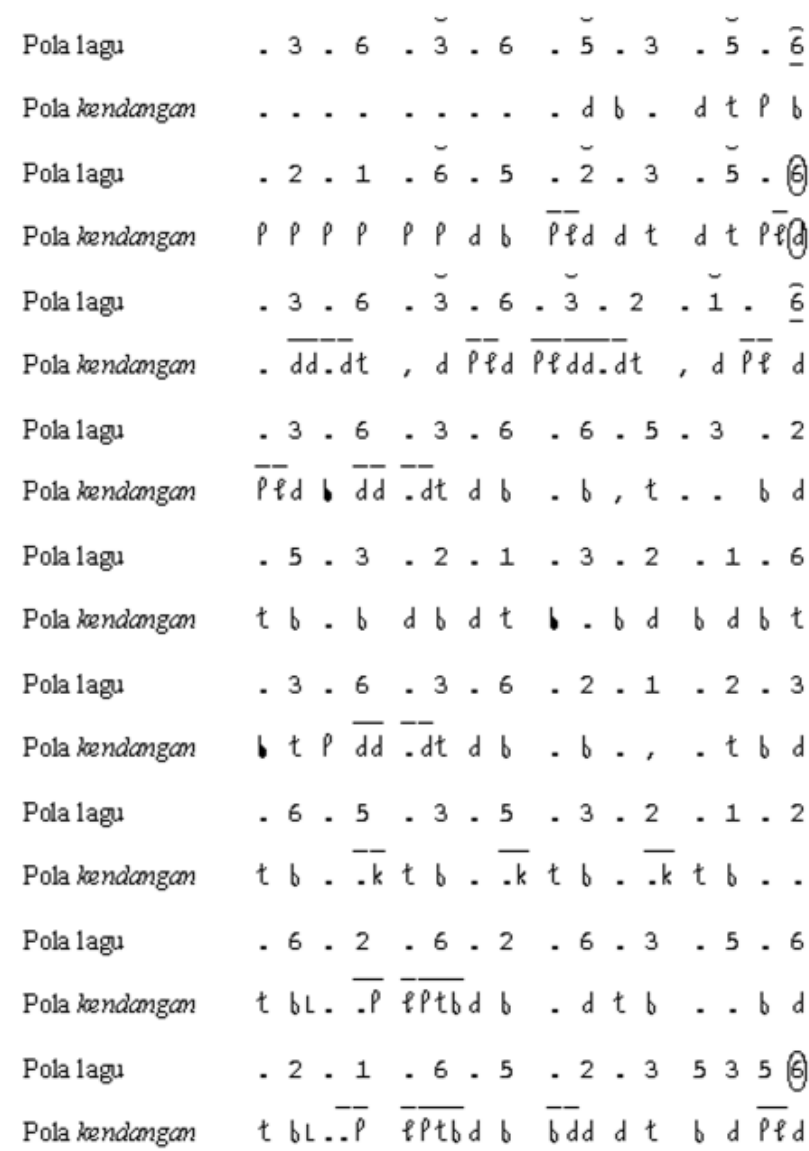

Pada baris pertama terdapat pola gerak kirig kemudian baris kedua merupakan gerak angkatan kiprah dengan pola kendangan angkatan kebar. Kemudian masuk pada Lancaran Gambuh, dipergunakan untuk mengiringi pola gerak lampah tiga, sabetan, cokehan dan trisig. Pada Lancaran Gambuh instrumen demung dimainkan dengan tabuhan balungan nibani dan instrumen saron dengan pola tabuhan kinthilan. Setelah Lancaran Gambuh, kemudian masuk pada pola gerak bapangan. Transisi dari gerak kombinasi ke bapangan terletak pada baris terakhir gatra 3 dan 4. Pola iringan gerak bapangan adalah sebagai berikut.

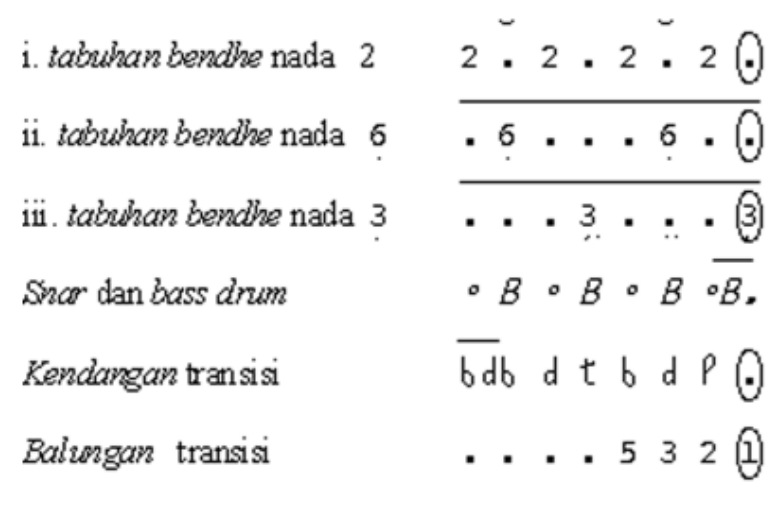

Pada pola ini, ricikan balungan dan instrumen kendang tidak ditabuh. Peran ricikan balungan diganti oleh instrumen bendhe, sedangkan kendang diganti oleh snar drum dan bass drum. Garap bendhe dengan pola imbal, snar drum dan bass drum membuat pola tabuhan dengan menyesuaikan pola geraknya. Pola ini dilakukan secara berulang-ulang dan perubahan gerak ditandai dengan pola kendangan transisi untuk menuju ke pola gerak selanjutnya. Pola gerak selanjutnya yaitu lampah mletik dengan pola iringan sebagai berikut.

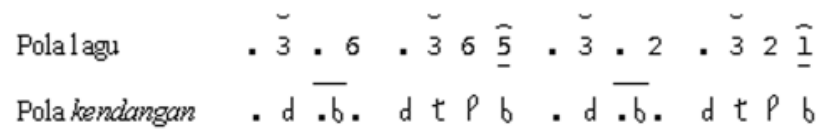

Pola ini disajikan satu kali, karena hanya digunakan sebagai jembatan dari gerak bapangan ke gerak drap. Berikut pola iringan gerak drap.

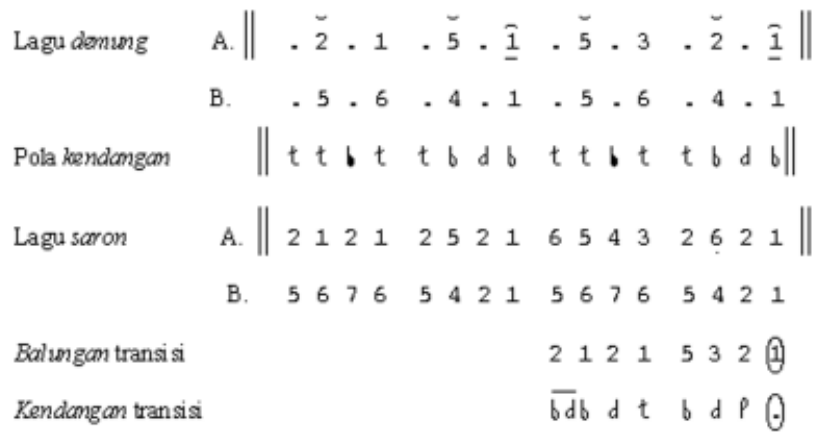

Pada pola ini instrumen demung dimainkan dengan tabuhan balungan nibani dan instrumen saron dengan balungan mlaku pola tabuhan 
kinthilan. Bagian A disajikan dua kali dan bagian B disajikan satu kali. Bagian A dan B disajikan secara berulang-ulang. Perubahan gerak ditandai dengan pola kendangan transisi untuk menuju ke pola gerak kebyak tangan.

Berikut pola iringannya.

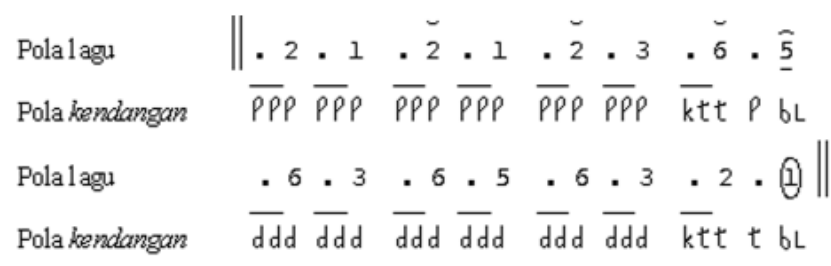

Pola ini disajikan dua kali, pengendang memberi tanda perpindahan gerak ke pola gerak kombinasi dengan pola kendangan transisi pada baris kedua gatra 3 dan 4 . Berikut pola iringan gerak kombinasi.

\begin{tabular}{|c|c|c|c|c|c|}
\hline Pola lagu & A. & . $6 \cdot 3$ & $.6 \cdot \hat{5}$ & $.6 \cdot 3$ & . $1 \cdot \hat{2}$ \\
\hline Pola kendangan & & $\overline{\text { topPpPp }}$ & $b . b$. & topPppp & 6.6. \\
\hline Pola lagu & B. & $\cdot 6 \cdot 3$ & $\cdot 6 \cdot \widehat{5}$ & $\cdot 6 \cdot 3$ & $\cdot 1 \cdot 2$ \\
\hline Pola kendangan & & $\overline{p P \rho} t d$ & $\overline{p P P} t d$ & $\overline{p P p} t d$ & . $d d d$ \\
\hline Pola lagu & C. & $.6 \cdot 3$ & $\cdot 6 \cdot \overline{5}$ & $\cdot 6 \cdot 3$ & $\cdot 2 \cdot 1$ \\
\hline Pola kendangan & &.$d b t$ & $b d P b$ & $\cdot t \cdot t$ & $\overline{b d b} d b$ \\
\hline Pola lagu & D. & .1. 15 & $.32 \overline{1}$ & $\overline{.1 .} 15$ & . 321 \\
\hline Pola kendangan & & $\cdot \bar{d} \cdot d t$ & $\overline{. P} \cdot P d$ & $t d . P$ & $\overline{. P} \cdot P_{C}$ \\
\hline Pola lagu & & & & $\cdot 5 \cdot 3$ & $\cdot 2 \cdot 1$ \\
\hline Pola kendangan & & & & $t d t d$ & $t d t$ \\
\hline & E. & $\begin{array}{llll} & . & 6 & \\
& & 5 & \\
3 & 5 & 3\end{array}$ & 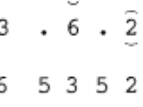 & $\begin{array}{cccc}\cdot & 1 & \cdot & 3 \\
3 & 1 & 2 & 3\end{array}$ & 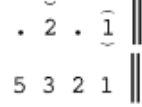 \\
\hline
\end{tabular}

Pola iringan di atas terdiri dari beberapa pola gerak tari di antaranya, untu walang, takuran, lampah mletik, ngombe muter, dan drap. Bagian A merupakan pola iringan dari pola gerak untu walang, disajikan satu kali. Bagian B merupakan pola iringan dari pola gerak takuran, disajikan dua kali. Bagian C merupakan pola iringan dari pola gerak lampah mletik, disajikan satu kali. Bagian D merupakan pola iringan dari pola gerak ngombe muter, disajikan dua kali. Bagian E baris pertama merupakan tabuhan demung dan baris kedua tabuhan saron yang disajikan secara berulangulang. Bagian E merupakan pola iringan dari pola gerak lampah mletik.

Pada pola iringan bagian A sampai E, pengendang tidak memainkan pola kendangan transisi tetapi langsung menyesuaikan pola gerak tari. Pengendang melakukan pola kendangan transisi pada bagian E gatra 3 dan 4 menuju pola gerak drap. Untuk bagian $\mathrm{E}$, instrumen demung dimainkan dengan tabuhan balungan nibani dan instrumen saron dengan balungan mlaku pola tabuhan kinthilan. Berikut pola iringan gerak drap.

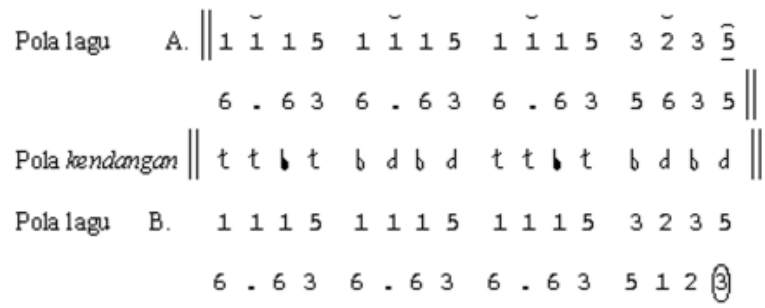

Pada pola ini, instrumen demung dimainkan dengan tabuhan balungan nibani dan instrumen saron dimainkan dengan balungan mlaku pola tabuhan kinthilan. Pada bagian A disajikan berulang-ulang dan bagian $\mathrm{B}$ untuk melakukan transisi menuju pola gerak kirig dengan pola kendangan transisi pada gatra 7 dan 8.

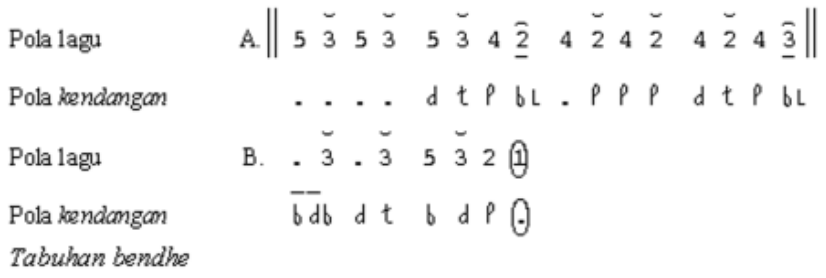

Pada pola ini memiliki bentuk yang mirip seperti bentuk sampak karena pada semua hitungan genap terdapat tabuhan kempul. Pada bagian A disajikan dengan tempo cepat dan berulang-ulang kemudian masuk bagian B untuk transisi ke pola iringan selanjutnya. Sebelum masuk ke pola gerak selanjutnya diselingi tabuhan bendhe terlebih dahulu sebagai jembatan dari gerak kirig ke gerak kudangan.

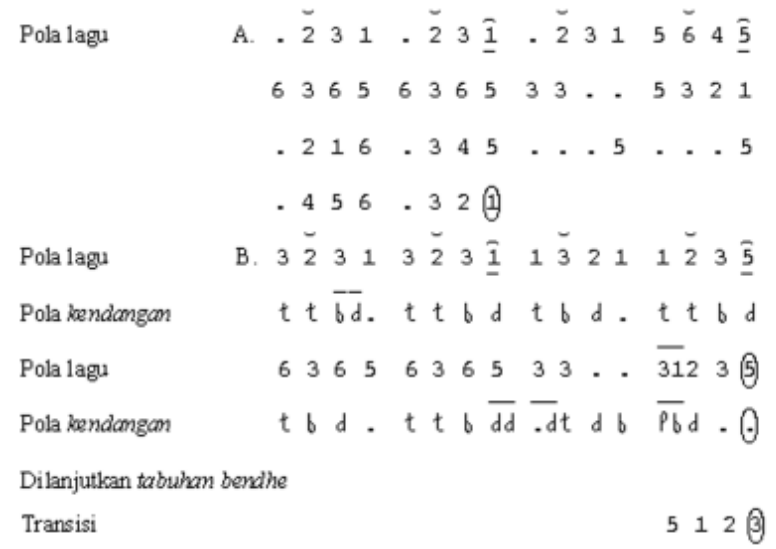




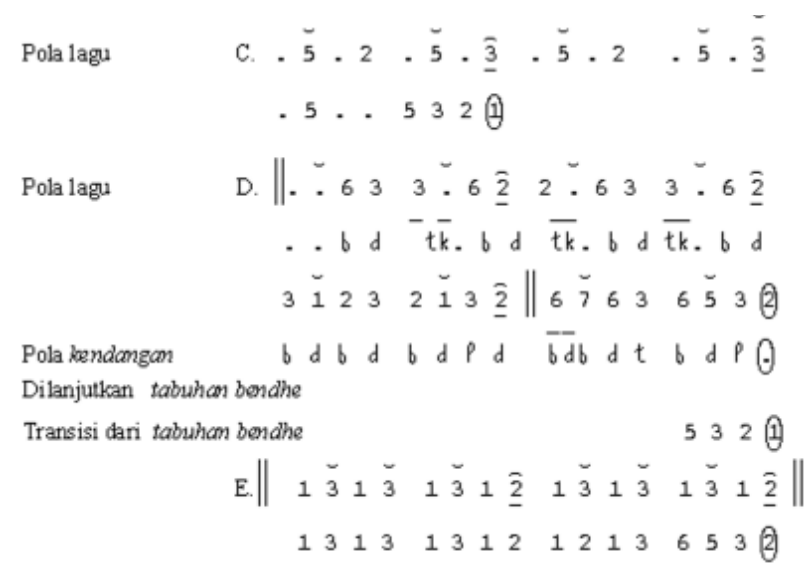

Bagian A terdiri atas pola gerak kudang jaran dan tolehan jangga. Pola gerak kudang jaran terletak pada baris 1,2 dan tolehan jangga pada baris ke-3, 4. Pola kendangan transisi terletak pada baris ke-4 untuk menuju bagian B merupakan pola iringan dari pola gerak sembahan. Bagian B disajikan satu kali diteruskan dengan tabuhan bendhe, pengendang melakukan pola kendangan transisi pada tabuhan bendhe untuk menuju ke bagian $\mathrm{C}$ merupakan pola iringan dari pola gerak tumpang tali, disajikan satu kali langsung menuju bagian D tanpa pola kendangan transisi. Bagian D merupakan pola iringan dari pola gerak jempolan. Perubahan gerak ditandai dengan pola kendangan transisi pada baris kedua gatra ke-3 dan 4 untuk menuju gerak kiprah. Pola Gerak kiprah diiringi dengan tabuhan bendhe pola imbal, kemudian menuju ke bagian $\mathrm{E}$ dengan pola kendangan transisi. Bagian E merupakan pola iringan dari pola gerak kudangan, baris pertama disajikan secara berulang-ulang dan baris kedua bila akan melakukan ke pola gerak selanjutnya.

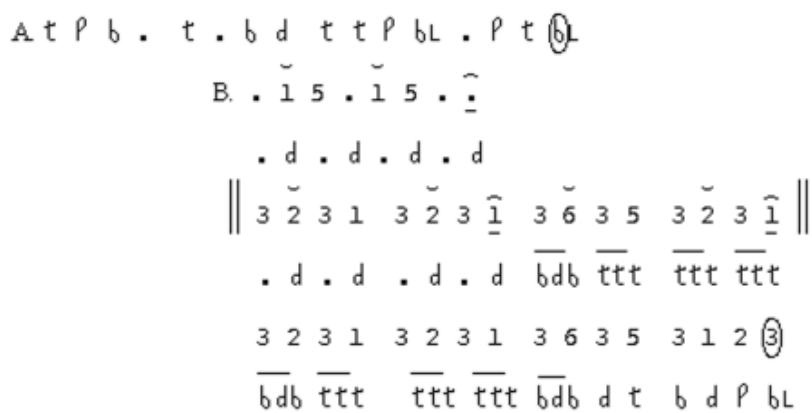

Bagian A merupakan pola iringan dari pola gerak malang kadak. Instrumen yang ditabuh hanya instrumen kendang dan hanya disajikan satu kali, kemudian masuk pada bagian B merupakan pola iringan dari pola gerak trisig. Pada bagian B baris pertama disajikan satu kali dan garap balungan dengan volume keras sedangkan baris kedua volume lirih dengan tempo cepat. Pada bagian B baris kedua disajikan secara berulang-ulang dan baris ketiga disajikan bila akan transisi ke gerak selanjutnya yaitu gerak kombinasi yang terdiri gerak kirig dan naik turun kuda. Pola iringan yang digunakan sama dengan pola iringan gerak kirig, kemudian transisi ke pola gerak minak jinggan. Berikut pola iringan gerak minak jinggan.

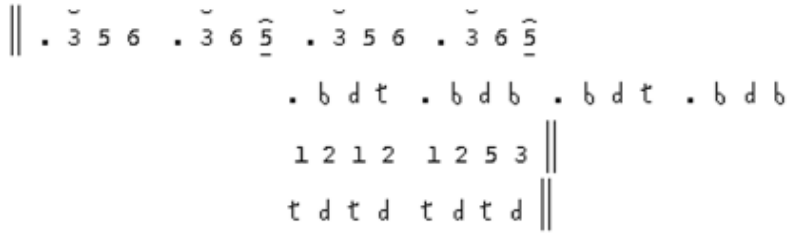

Pola iringan di atas disajikan dua kali, kemudian menuju pola gerak kiprah dengan pola iringan transisi. Berikut pola iringan transisi angkatan gerak kiprah.

$$
\begin{aligned}
& .676235 \\
& . d b t b d P \theta
\end{aligned}
$$

Pada pola gerak kiprah ricikan balungan tidak ditabuh tetapi diperankan oleh instrumen bendhe dengan pola tabuhan imbal. Pola gerak kiprah disajikan berulang-ulang, perpindahan ke pola gerak selanjutnya ditandai dengan pola kendangan transisi. Pola gerak selanjutnya yaitu pola gerak timpangan, lampah tiga dan lenjitan. Berikut pola iringan transisi dari gerak kiprah ke timpangan.

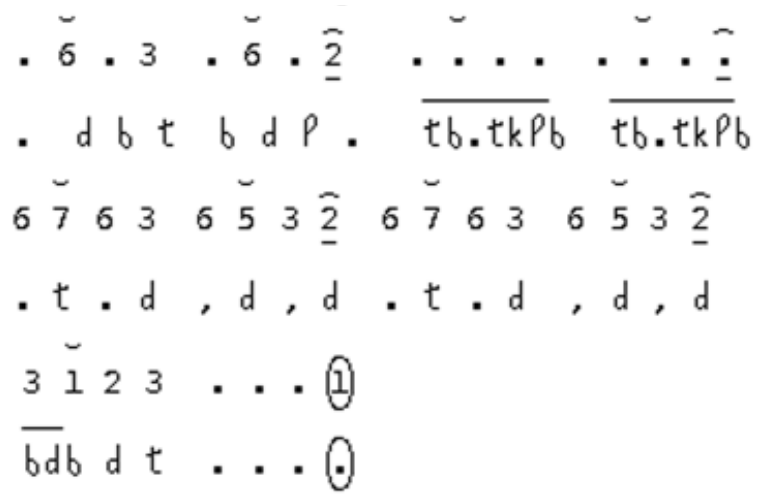

Pola iringan gerak timpangan terletak pada baris pertama sedangkan gerak lampah tiga pada baris kedua, kemudian pola kendangan transisi pada baris ketiga menuju pola gerak lenjitan. pola lenjitan disajikan dengan laras slendro ditabuh pada gong 1 baris ketiga. Berikut ini pola iringan gerak lenjitan. 


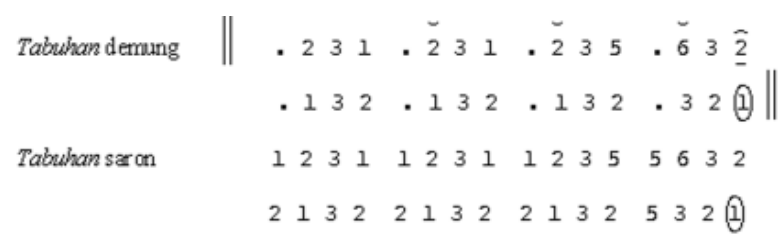

Pola iringan gerak lenjitan disajikan dua kali, kemudian transisi angkatan gerak kiprah untuk menuju pola gerak kiprah. Pola gerak selanjutnya ditandai dengan kendangan transisi yaitu gerak bokongan, naik turun kuda, kirig, takuran, dan teposan, kemudian menuju pola gerak kiprah. Pola iringan ini kembali disajikan dengan laras pelog. Berikut ini pola iringan gerak bokongan.

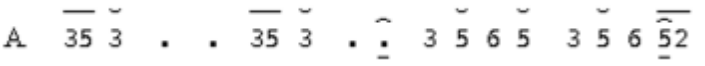

$$
\begin{aligned}
& \overline{t b} p . . \overline{t b} p \ldots . . . . . . .
\end{aligned}
$$

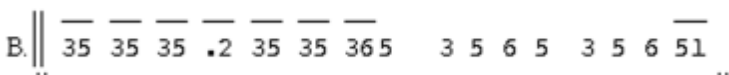

$$
\begin{aligned}
& \|\overline{k d} \cdot \bar{t} \overline{k d} . \bar{t} \overline{k d} \cdot \overline{. t} \overline{k d} . . . . . . . \bar{t}\| \\
& \begin{array}{llllllllllllllll}
23 & 23 & 23 & .1 & \overline{23} & \overline{23} & \overline{265} & 3 & 5 & 6 & 5 & 3 & 5 & 6 & \overline{\tilde{5} 2}
\end{array} \\
& \text { C. } \overline{12} \overline{12} \overline{12} \overline{.1} \overline{23} \overline{23} \overline{265} \ldots .532 \text { (1) }
\end{aligned}
$$

Pola iringan di atas merupakan pola iringan dari gerak bokongan, pada bagian A disajikan satu kali, bagian B disajikan berulang-ulang dan bagian C untuk transisi menuju pola gerak naik turun kuda. Perubahan gerak ditandai dengan pola kendangan transisi pada gatra 3 dan 4 . berikut ini iringan pola gerak naik turun kuda.

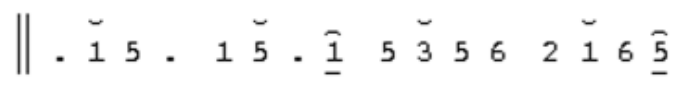

$$
\begin{aligned}
& \overline{-P} \cdot P P \overline{-P} \cdot P \text { P } \overline{-d} \cdot d t b d P b \mathrm{~b} \\
& \text { - } 15 \cdot 15 \cdot 15356531 \hat{2} \\
& 32.32365 .32 \cdot 2365
\end{aligned}
$$

Transisi $5 \begin{array}{llll}5 & 1 & 2 & 3\end{array}$

Pola iringan di atas disajikan dua kali, pola gerak selanjutnya adalah gerak kirig dengan kendang memainkan pola kendangan transisi. Ketika transisi, terjadi perubahan nada balungan, perubahan itu terletak pada baris ketiga gatra terakhir menjelang gong, nada balungan 236 5 berubah menjadi 51223 . Setelah pola gerak kirig kendang dimainkan dengan pola kendangan transisi untuk menuju pola gerak takuran, teposan dan kembali ke gerak kiprah.

$$
\begin{aligned}
& \text { A. . } 15 . \breve{14} \cdot . \check{1} 54352 \hat{I} \\
& \text {..15..14 .. } 154321 \\
& \overline{P P} P \mathrm{t} d \overline{P P} P \mathrm{t} d \overline{P P} P \mathrm{t} d \mathrm{t} d \mathrm{t} d \\
& \text { B. . . } 13.123 .0612312 \\
& \text {. . } 356365.3 .25321 \\
& \text {. } t d d^{2} \cdot t d . . t d t d t d
\end{aligned}
$$

Bagian A merupakan pola iringan dari gerak takuran, sedangkan bagian B merupakan pola iringan dari gerak teposan, perpindahan dari gerak takuran ke gerak teposan tidak ditandai dengan pola kendangan transisi. Setelah gerak teposan kemudian menuju gerak kiprah dengan pola angkatan kiprah. Pola gerak selanjutnya yaitu gerak sembirang, kirig, dan congklang. Berikut pola iringannya.

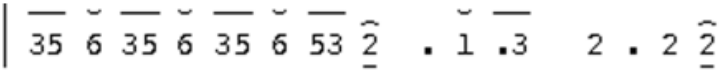

$$
\begin{aligned}
& \overline{t b} p \overline{t b} p \overline{t b} p b \quad d \cdot d \overline{. t} d . d d \\
& \cdot 6 \cdot 3 \cdot 6 \cdot 2 \\
& b d b d b d t
\end{aligned}
$$

Pola di atas disajikan dengan gamelan laras slendro dilakukan dua kali, sebagai tanda perpindahan menuju pola gerak kirig kendang dimainkan dengan pola kendangan transisi. Berikut pola iringan gerak kirig dengan laras slendro.

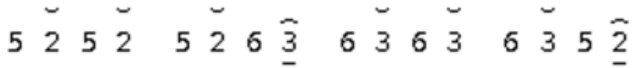

$$
\begin{aligned}
& 5 \begin{array}{lllllll}
5 & 2 & 5 & 2 & 6 & 5 & 3
\end{array}
\end{aligned}
$$

Pola ini hanya disajikan satu kali. Pola kendangan gerak kirigsama dengan pola kendangan gerak kirig sebelumnya dan pola kendangan transisi terletak pada gatra 5 dan 6 untuk menuju pola gerak congklang. Pola iringan gerak congklang disajikan dengan laras pelog dan pola tabuhan snar dan bass drum sama dengan pola iringan gerak congklang sebelumnya. Berikut pola iringannya.

$$
\begin{aligned}
& . .11 . .11 \quad . .35 \text {.6. } 2 \hat{\mathrm{I}} \\
& . .11 . .11 . .35 \overline{.6} \cdot 5 \hat{3} \\
& .576 .576 \cdot 5 \cdot 4 \cdot 2 \cdot \hat{I} \\
& .576 .576 .55 \cdot 4 \cdot 5 \cdot 42 \hat{I}
\end{aligned}
$$




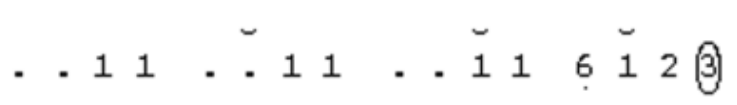

Pola iringan gerak congklang di atas disajikan satu kali. Pola di atas merupakan bentuk lancaran, namun pada baris keempat terjadi perubahan bentuk gending, karena dalam satu gongan terdapat 18 sabetan balungan. Letak dan jumlah tabuhan kempul pada baris keempat sama dengan bentuk lancaran, namun perbedaan terletak pada jarak antara tabuhan kempul ketiga dan letak tabuhan gong. Pada bentuk lancaran jarak antara kempul ketiga ke gong hanya satu sabetan balungan, sedangkan bentuk gending pada baris keempat jarak antara kempul ketiga ke gong terdiri atas tiga sabetan balungan. Tanda perpindahan ke pola gerak selanjutnya yaitu gerak kirig terletak pada baris kelima gatra 3 dan 4 dengan pola kendangan transisi. Pola iringan gerak kirig sama dengan pola iringan gerak kirig sebelumnya, hanya berbeda pada nada seleh gong. Pada pola iringan gerak kirig sebelumnya nada seleh gong 1 sedangkan pola iringan gerak kirig ini nada seleh gong 5. Pola gerak selanjutnya yaitu gerak kebyak tangan dan gerak kombinasi dari gerak kirig dan sembirang. Berikut pola iringannya.

$$
\begin{aligned}
& \text { A. || } \begin{array}{llllllllllllllll||}
3 & 6 & 3 & 5 & 3 & \breve{6} & 3 & 5 & 3 & \overline{6} & 3 & 5 & 1 & \overline{2} & 3 & \overline{5}
\end{array} \\
& \begin{array}{llllllllllllllll}
3 & 6 & 3 & 3 & 6 & 3 & 5 & 3 & 6 & 5 & 6 & 1 & 2 & 3
\end{array}
\end{aligned}
$$

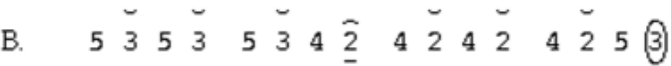

$$
\begin{aligned}
& .13 \cdot . \cdot(1)
\end{aligned}
$$

Bagian A merupakan pola iringan gerak kebyak tangan, pada pola iringan ini volume ricikan balungan digarap keras dan lirih. Pada gatra 1, 2 , 3 volume lirih dan pada gatra 4 volume keras. Pola kendangan kebyak tangan sama dengan pola kendangan gerak kebyak tangan sebelumnya. Bagian A baris pertama disajikan berulang-ulang dan baris kedua disajikan untuk transisi ke bagian B. Bagian B merupakan pola iringan kombinasi dari gerak kirig dan sembirang. Pola gerak selanjutnya yaitu gerak lenjitan, berikut pola iringannya.

$$
\begin{aligned}
& \text { \|. . . } \\
& t \cdot t \cdot t \cdot t \cdot t \cdot t \cdot t \overline{b 6 b 6 b P} \\
& \text {. . } \\
& \overline{t P . P t P . P} \overline{t P . P t P . b} d b \overline{d b} \text {. t } \overline{b 6 b b}
\end{aligned}
$$

Pada pola iringan gerak lenjitan kendang dimainkan dengan pola kendangan kenthrungan atau celonan dengan tempo lambat sedangkan instrumen saron dengan pola tabuhan imbal. Pola iringan gerak lenjitan disajikan secara berulangulang. Perubahan gerak ditandai dengan pola kendangan transisi untuk menuju pola gerak kirig, pola iringan gerak kirig sama dengan pola iringan gerak sebelumnya dengan nada seleh gong 1, kemudian transisi ke pola gerak kombinasi yang terdiri dari gerak kosodan, drap, gebesan, liyepan, perang jaran, drap dan kembali ke pola gerak kirig. Berikut pola iringannya.

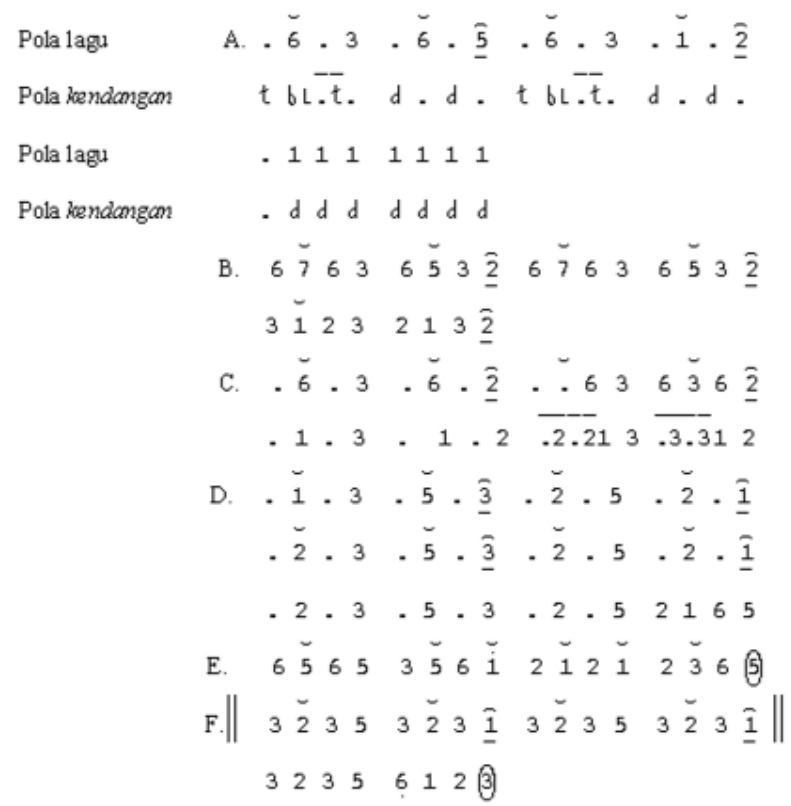

Bagian A baris pertama merupakan pola iringan gerak kosodan dan baris kedua gerak drap. Bagian B merupakan pola iringan gerak gebesan, pola kendangan gebesan sama dengan pola kendangan gebesan sebelumnya. Bagian C merupakan pola iringan gerak timpangan, pola kendangan timpangan sama dengan pola kendangan timpangan sebelumnya. Bagian D merupakan pola iringan gerak perang jaran, pola kendangan ini sama dengan pola kendangan gerak kebyak tangan. Kemudian kendang dimainkan dengan pola kendangan transisi pada baris ketiga gatra 3 dan 4 untuk menuju bagian E. Bagian E merupakan pola iringan gerak kombinasi, gerak kombinasi terdiri dari gerak kirig dan naik turun kuda. Pola kendangan gerak ini sama dengan pola kendangan gerak kirig, bagian E disajikan dua kali langsung menuju bagian $\mathrm{F}$ tanpa kendangan transisi. Bagian F merupakan pola iringan gerak drap, pada baris pertama disajikan berulang-ulang dan baris kedua 
disajikan untuk menuju gerak kirig, kemudian dilanjutkan tari gendruwo, berikut ini iringan tari gendruwo.

$$
\begin{aligned}
& \begin{array}{c}
\text { A. } \| . \cdots \\
\text { Pola kendangan }
\end{array} \\
& \overline{t t} t \bar{t} \overline{t t} \overline{b d b} \overline{t t t} \overline{b d b} \overline{t t t} \overline{b d b} \overline{t t t} \\
& \text {. t t bl . t d b. . d t b. . bd } \\
& \text {. t bd. t bd.t bd. t bd } \\
& \text {. } t t b l \cdot t d b . d t b . . b d \\
& \text {. bl . . } \bar{b} \overline{d b} \overline{t t t} \bar{b} \overline{d b} \overline{t t t} \bar{b} \overline{d b} \bar{t} \bar{t} t
\end{aligned}
$$

Iringanurtuk perang

$$
\begin{aligned}
& \text { в. }\|\cdot 1 \cdot 5 \cdot 1 \cdot 5 \cdot 1 \cdot 6 \cdot 6 \cdot 1\| \\
& \text { C. } 5 \breve{5} 5 \breve{5} \quad 3 \breve{3} 3 \breve{3} 6 \breve{6} 6 \breve{6} \quad 2 \breve{2} 2 \underline{\underline{2}} \\
& 555533336666216 \text { (5) }
\end{aligned}
$$

Bagian A disajikan secara berulang-ulang, kemudian masuk bagian B merupakan gending iringan adegan perang gendruwo dengan Wirayuda diisi dengan Rambangan Pangkur, kemudian masuk bagian $\mathrm{C}$ adegan kalahnya gendruwo yang bersamaan dengan keluarnya Singalodra. Berikut iringan adegan perang Singalodra dengan Wirayuda.

$$
\begin{array}{r}
A \| \cdot \tilde{6} \cdot 5 \cdot \tilde{6} \cdot \tilde{5} \cdot \tilde{6} \cdot 5 \cdot 6 \cdot \hat{5} \\
\cdot 6 \cdot 5 \cdot 6 \cdot 5 \cdot 5 \cdot 1 \cdot 236
\end{array}
$$

Setelah selesai rambangan, adegan kalahnya Singalodra diiringi dengan bentuk sampak irama cepat kemudian masuk pada bagian slompret. Berikut pola iringannya.

$$
\begin{aligned}
& \| \begin{array}{|llllllllllllllll||}
5 & 5 & 5 & 5 & 3 & 3 & 3 & 3 & 6 & 6 & 6 & 6 & 2 & 2 & 2 & \underline{2}
\end{array}
\end{aligned}
$$

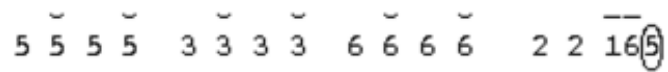

$$
\begin{aligned}
& \left\|\begin{array}{llllllllllllllll}
6 & 5 & 6 & 5 & 3 & 5 & 6 & 1 & 2 & 1 & 2 & 1 & 2 & 3 & 6 & 5
\end{array}\right\| \\
& 65652236 \text { ( } \\
& \|\cdot \breve{6} \cdot 5 \cdot \overline{6} \cdot \underline{5} \cdot \overline{6} \cdot 5 \cdot \overline{6} \cdot \underline{5}\|
\end{aligned}
$$

Pola kendangan gerak tari Slompret

$$
\begin{aligned}
& \text {...... . d d t . d. } \\
& \ldots t t . . t d . . t d
\end{aligned}
$$

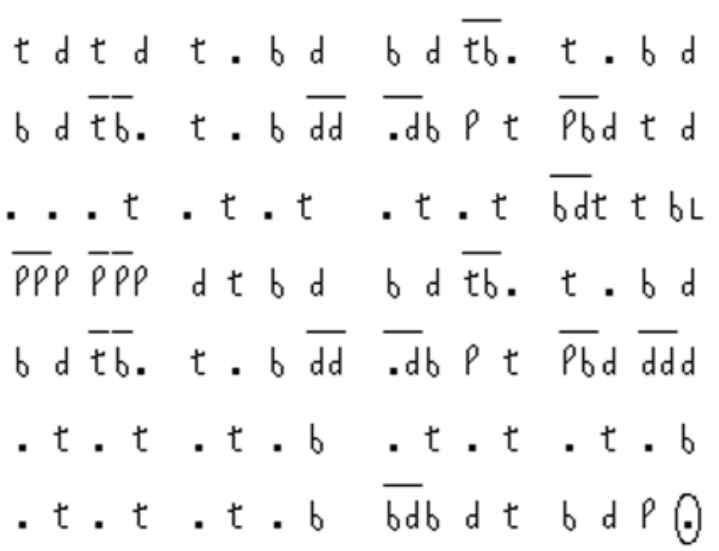

Setelah bagian slompret pengendang memberi tanda perubahan ke pola gerak kombinasi yang terdiri gerak sirig, oyogan dan kirig dengan pola kendangan transisi. Berikut pola iringannya.

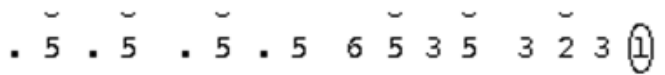

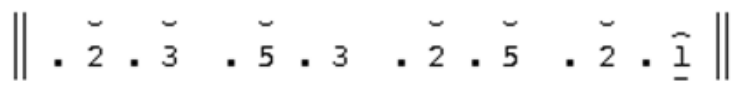

Baris pertama disajikan satu kali dan baris kedua disajikan berulang-ulang kemudian kendang memberi tanda perubahan ke pola gerak selanjutnya dengan pola kendangan transisi menuju pola iringan gerak cokehan, drap dan kirig.

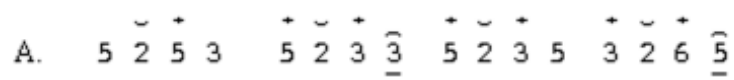

$$
\begin{aligned}
& 6355663556356532 \text { (1) } \\
& \text { B. } 63565365635653312 \\
& \begin{array}{llllllllllllllll}
3 & 1 & 2 & 3 & 2 & 1 & 3 & 2 & 3 & 1 & 2 & 3 & 2 & 1 & 6
\end{array} \\
& 635653656356 \quad 123
\end{aligned}
$$

Bagian A merupakan pola iringan gerak cokehan, pola kendangan cokehan sama dengan pola kendangan gerak bapangan, kemudian kendang memberi tanda perubahan untuk menuju bagian B. Pada bagian B instrumen bendhe juga ditabuh dengan pola imbal. Bagian B merupakan pola iringan gerak drap, bagian B baris pertama dan kedua disajikan berulang-ulang, sedangkan baris ketiga disajikan untuk transisi menuju gerak kirig. Pola iringan gerak kirig sama dengan sebelumnya. Pola gerak selanjutnya yaitu gerak kombinasi yang terdiri gerak untu walang, drap dan lampah mletik, berikut pola iringannya. 


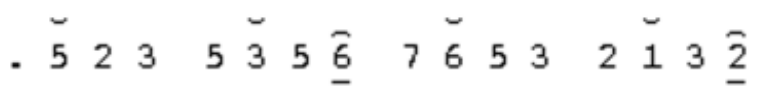

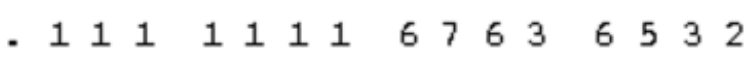

$\begin{array}{llllllllllllllll}6 & 7 & 6 & 3 & 6 & 5 & 3 & 2 & -1 & 2 & 3 & 2 & 1 & 3 & 2\end{array}$

Baris pertama merupakan pola iringan gerak untu walang dan baris kedua gatra 1, 2 merupakan gerak drap, sedangkan baris kedua mulai gatra ke 3, 4 merupakan gerak lampah mletik, kemudian pengendang memberi tanda perubahan dengan pola kendangan transisi untuk menuju gerak drap dan kirig. Berikut iringannya.

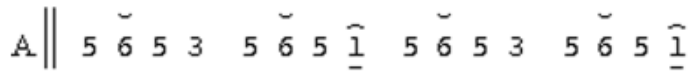

$$
\begin{aligned}
& 232123512321235 \text { (1) } \\
& 56535512 \text { (3) }
\end{aligned}
$$

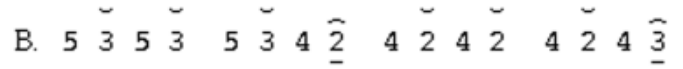

$$
\begin{aligned}
& \begin{array}{llllllll}
5 & 3 & 5 & 3 & 5 & 3 & 2
\end{array} \\
& \text {. } d d t \cdot d . \theta
\end{aligned}
$$

Pada bagian A pola iringan di atas merupakan pola iringan gerak drap, baris pertama dan kedua disajikan dua kali sedangkan baris ketiga disajikan untuk transisi ke bagian B. Bagian B merupakan pola iringan gerak kirig. Pola iringan gerak kirig di atas merupakan pola iringan terakhir dari seluruh penyajian rangkaian iringan kuda lumping. Suwuk terletak pada bagian B baris kedua, yang dilanjutkan dengan gending penutup.

\section{Analisis}

Pada deskripsi di atas dapat kita lihat bahwa iringan kuda lumping Ngesti Budaya mengalami banyak perkembangan. Perkembangan itu dapat dilihat dari berbagai aspek yaitu bentuk, gending, lagu atau melodi serta peran iringan. Pada awalnya bentuk gending yang digunakan hanya bentuk gending khusus kuda lumping, namun pada perkembangannya bentuk gending yang digunakan meliputi gangsaran, lancaran, sampak, dan beberapa bentuk di luar tradisi karawitan Jawa.

Aspek lagu merupakan aspek yang paling menonjol dalam perkembangannya, hal itu dapat dilihat dari banyaknya variasi lagu yang digunakan. Beberapa variasi lagu yang terdiri dari 28 janis disesuaikan dengan 28 pola gerak tarinya, jadi pola gerak pada tari kuda lumping saat ini tidak hanya dibedakan oleh pola kendangan saja, namun dapat juga dibedakan dengan pola lagu. Hal itu sangat berbeda dengan iringan yang digunakan sebelumnya, yaitu pola gerak hanya dibedakan oleh pola kendangan. Karena banyaknya variasi lagu yang digunakan dalam penyajian iringan kuda lumping, maka masing-masing penabuh dituntut harus hafal urutan pola iringannya karena berhubungan erat dengan pergantian pola gerak tari.

Dalam perkembangannya iringan tidak hanya mengiringi tari, namun iringan mampu menjadi bagian yang terpenting dari tari dan mempunyai peran yang sama dalam penyajiannya. Hal itu terlihat dari usaha membuat berbagai garap iringan baru, garapan tersebut melekat dengan pola gerak tarinya, yang akhirnya garap iringan tersebut dapat mempertegas karakter tari, nguripke joged dan membangun suasana cerita tari. Berbeda dengan iringan versi R. Soebagyono yang terlihat hanya sebagai pelayan tari saja, salah satu pemimpin penari menggunakan properti cambuk yang berfungsi sebagai aba-aba tanda perpindahan pola gerak. Fungsi cambuk sekarang ini lebih cenderung sebagai properti, tidak selalu dipergunakan untuk perpindahan ragam tari atau iringannya.

\section{Penutup}

Kuda lumping Ngesti Budaya merupakan salah satu kesenian tradisional yang hidup dan berkembang di wilayah Kabupaten Temanggung. Pada awalnya merupakan tari kuda lumping karya Almarhum R. Soebagyono. Bentuk kuda lumping Ngesti Budaya sudah banyak mengalami perubahan dari bentuk semula, sebab suatu kesenian memiliki daya kultur untuk berkembang sesuai dengan perkembangan masyarakatnya.

Perkembangan kuda lumping Ngesti Budaya dapat dilihat dari aspek gerak tari, garap iringan, tata teknik pentas, tata rias, properti, tempat dan waktu pementasan. Kuda lumping Ngesti Budaya memiliki bentuk dan ciri-ciri yang khas terutama peran iringannya. Pada perkembangannya, iringan kuda lumping Ngesti Budaya tidak hanya mengiringi tari, namun menjadi bagian yang terpenting dari tari, memiliki peran yang sama dalam penyajiannya. Hal itu terlihat dari garapan iringan baru yang melekat dengan pola 
gerak tarinya. Pada akhirnya iringan tersebut dapat mempertegas karakter tari, nguripke joged dan membangun suasana cerita tari. Dinamika pertunjukan tidak hanya ditunjukkan oleh variasi gerak dan pola kendangan tetapi juga ditunjang oleh variasi melodi yang berubah-ubah. Pada mulanya, setiap pergantian ragam tari selalu ditandai dengan ragam kiprahan, tetapi pada penyajian kuda lumping Ngesti Budaya sekarang tidak selalu ditandai dengan ragam kiprahan, namun ditandai dengan pergantian pola iringan.

\section{Kepustakaan}

Supanggah, Rahayu. 2002. Bothekan Karawitan I. Jakarta: Masyarakat Seni Pertunjukan Indonesia.

Surakarta: ISI Press
Soedarsono, R.M. 1992. Pengantar Apresiasi Seni. Jakarta: Balai Pustaka.

\section{Informan}

Didik Nuryanto. 42 tahun. Pegawai Dinas Kebudayaan Pariwisata, Pemuda dan Olahraga Kabupaten Temanggung, Desa Kowangan Kecamatan Temanggung Kabupaten Temang gung.

Suroyo. 40 tahun. Ketua Kesenian Kuda Lumping Ngesti Budaya, Desa Jragan Kecamatan Tembarak Kabupaten Temanggung.

Turyono. 59 tahun. Kepala Dusun Jragaran Tembarak Temanggung.

\section{Sumber audio visual}

Video CD Kuda lumping Ngesti Budaya (koleksi toko kaset Kembar Jaya Temanggung). 